\title{
PENGUKURAN KEPUASAN NASABAH TERHADAP IMPLEMENTASI SYARIAH MARKETING PADA PT. BANK SYARIAH MANDIRI CABANG MALANG
}

\author{
Irmayanti Hasan \\ Fakultas Ekonomi UIN Maulana Malik Ibrahim Malang \\ irmaa.hasan@gmail.com
}

\begin{abstract}
Competition is increasingly competitive in the development of Islamic bank in Indonesia and policy enforcement office channeling makes the atmosphere seizure of shari'ah loyalists consumers increasingly viscous. The phenomenon of this competition requires marketers to constantly innovate marketing strategies. One step to achieve this is through the implementation of sharia marketing.

The approach used in this study is a survey approach and type of research is quantitative. This study used 16 items, then the sample is 80 customers.

The results of this study are customers already feel very satisfied with the services of employees of PT. Bank Syariah Mandiri Malang Branch, but the performance of employees of PT. Bank Syariah Mandiri Malang Branch must still be improved. There are several strategies to increase customer satisfaction, there are some things that should be emphasized and some are already well do not need to be prioritized, but still need to be considered by PT. Bank Syariah Mandiri Malang Branch.
\end{abstract}

Keywords: Marketing Syariah, customer satisfaction

\section{PENDAHULUAN}

Perkembangan perbankan syariah di Indonesia telah menjadi tolak ukur keberhasilan eksistensi ekonomi syariah. Tidak hanya itu, di tengah-tengah krisis keuangan global yang melanda dunia, lembaga keuangan syariah membuktikan daya tahannya dari terpaan krisis. Lembaga-lembaga keuangan syariah tetap stabil dan memberikan keuntungan, kenyamanan serta keamanan bagi para pemegang sahamnya, pemegang surat berharga, peminjam dan para penyimpan dana di bank-bank syariah.

Marketing menurut bahasa, yaitu pemasaran, sedangkan, marketing menurut istilah adalah memindahkan barang dan jasa dari pemasok ke konsumen. Termasuk di dalamnya perancang dan pembuatan produk, pengembangan, pendistribusian iklan, promosi, dan publikasi, serta analisa pasar untuk menentukan pasar yang sesuai. Berangkat dari definisi pemasaran yang telah disepakati dewan World Marketing Association (WMA) dalam World Marketing Conference di Tokyo pada April 1998, Muhammad Syakir Sula mendefinisikan pemasaran dalam perspektif syariah sebagai berikut. Pemasaran syariah adalah sebuah disiplin bisnis strategis yang mengarahkan proses penciptaan, penawaran, dan perubahan values dari satu inisiator kepada stakeholdersnya, yang dalam keseluruhan prosesnya sesuai dengan akad dan prinsipprinsip muamalah dalam Islam.

Persaingan yang semakin kompetitif inilah yang saat ini sedang terjadi di dunia perbankan. Hal ini terjadi seiring dengan semakin pesatnya perkembangan bank syari'ah di Indonesia. Selain itu, kebijakan pemberlakuan office chanelling membuat suasana perebutan konsumen loyalis syari'ah semakin kental. Terlepas dari semua itu, pada dasarnya persaingan utama bank syari'ah, khususnya dengan PT. Bank Syariah Mandiri Cabang Malang, bukanlah dengan sesama perbankan syari'ah, tetapi dengan perbankan 
konvensional itu sendiri. Fakta menunjukkan bahwa total aset perbankan syari'ah masih sangat kecil dibandingkan dengan total aset perbankan Indonesia.

Fenomena persaingan ini menuntut para pemasar untuk selalu menginovasi strategi pemasarannya. Salah satu langkah untuk mencapai hal tersebut adalah melalui implementasi syariah marketing.

Tujuan Penelitian adalah untuk mengetahui tingkat kepuasan nasabah terhadap implementasi Syariah Marketing pada PT. Bank Syariah Mandiri Cabang Malang. Dan untuk mengetahui upaya meningkatkan tingkat kepuasan nasabah terhadap implementasi Syariah Marketing pada PT. Bank Syariah Mandiri Cabang Malang.

\section{METODE PENELITIAN}

Penelitian ini dilakukan di PT. Bank Syariah Mandiri Cabang Malang, Jalan Letjen Sutoyo Malang. Pendekatan yang digunakan dalam penelitian ini adalah pendekatan survei yaitu penelitian yang mengambil sampel dari satu populasi dan menggunakan kuesioner sebagai alat pengumpulan data yang pokok, Singarimbun (1995: $3)$.

Penentuan jumlah sampel menggunakan pendekatan dari Maholtra (1993:622) jumlah sampel atau responden dengan jumlah populasi yang tak terbatas paling sedikit empat atau lima kali jumlah item yang akan diteliti. Dalam penelitian ini digunakan 16 item, maka sampel yang digunakan adalah 80 nasabah.

Tabel 1. Daftar Operasional Variabel

\begin{tabular}{|c|c|c|}
\hline VARIABEL & HARAPAN (X) & PENILAIAN (Y) \\
\hline \multirow[t]{2}{*}{$\begin{array}{l}\text { Variabel teistis } \\
\text { (Rabbaniyyah) }\end{array}$} & $\begin{array}{l}\text { 1. Karyawan bank selalu patuh } \\
\text { dan taat pada SOP saat } \\
\text { melaksanakan tugasnya }\end{array}$ & $\begin{array}{l}\text { 1. Karyawan bank selalu patuh } \\
\text { dan taat pada SOP saat } \\
\text { melaksanakan tugasnya }\end{array}$ \\
\hline & $\begin{array}{l}\text { 2. Karyawan bank selalu jujur } \\
\text { dalam } \\
\text { produknya }\end{array}$ & $\begin{array}{l}\text { 2. Karyawan bank selalu jujur } \\
\text { dalam memasarkan } \\
\text { produknya }\end{array}$ \\
\hline \multirow[t]{2}{*}{$\begin{array}{ll}\text { Variabel } & \text { etis } \\
(\text { Akhaqiyyah }) & \end{array}$} & $\begin{array}{l}\text { Karyawan bank mempunyai } \\
\text { akhlak yang baik (sopan dan } \\
\text { santun). }\end{array}$ & $\begin{array}{l}\text { 1. Karyawan bank mempunyai } \\
\text { akhlak yang baik (sopan } \\
\text { dan santun). }\end{array}$ \\
\hline & $\begin{array}{l}\text { 2. Karyawan bank mempunyai } \\
\text { etika yang baik. }\end{array}$ & $\begin{array}{l}\text { 2. Karyawan bank mempunyai } \\
\text { etika yang baik. }\end{array}$ \\
\hline \multirow[t]{2}{*}{$\begin{array}{l}\text { Variabel Realistis (Al } \\
\text { Waqi'iyyah) }\end{array}$} & $\begin{array}{l}\text { Karyawan } \\
\text { berpenampilan bersih, rapi } \\
\text { dan bersahaja dan berbusana } \\
\text { muslim }\end{array}$ & $\begin{array}{l}\text { 1. Karyawan bank } \\
\text { berpenampilan bersih, rapi } \\
\text { dan bersahaja dan } \\
\text { berbusana muslim }\end{array}$ \\
\hline & $\begin{array}{l}\text { 2. Karyawan bank selalu bekerja } \\
\text { profesional dan } \\
\text { berpengalaman (menguasai } \\
\text { dengan betul tentang produk } \\
\text { yang ditawarkan) }\end{array}$ & $\begin{array}{l}\text { 2. Karyawan bank selalu } \\
\text { bekerja profesional dan } \\
\text { berpengalaman (menguasai } \\
\text { dengan betul tentang } \\
\text { produk yang ditawarkan) }\end{array}$ \\
\hline \multirow[t]{2}{*}{$\begin{array}{l}\text { Variabel Humanistis } \\
\text { (Insaniyyah) }\end{array}$} & $\begin{array}{llr}\text { Karyawan } & \text { bank } \\
\text { mempunyaiempati } & \text { yang } \\
\text { tinggi terhadap } & \text { semua } \\
\text { nasabah }\end{array}$ & $\begin{array}{ll}\text { Karyawan } & \text { bank } \\
\text { mempunyaiempati } & \text { yang } \\
\text { tinggi terhadap semua } \\
\text { nasabah }\end{array}$ \\
\hline & $\begin{array}{l}\text { 2. Karyawan bank selalu } \\
\text { bersedia membantu kesulitan }\end{array}$ & $\begin{array}{r}\text { bank selalu } \\
\text { membantu }\end{array}$ \\
\hline
\end{tabular}




\begin{tabular}{|l|l|l|}
\hline & $\begin{array}{l}\text { yang dihadapi nasabah dalam } \\
\text { segala hal }\end{array}$ & $\begin{array}{l}\text { kesulitan yang dihadapi } \\
\text { nasabah dalam segala hal }\end{array}$ \\
\hline
\end{tabular}

Skala likert pada variabel harapan meliputi :

1. Sangat Berpengaruh diberi nilai lima

2. Berpengaruh diberi nilai empat

3. Cukup Berpengaruh diberi nilai tiga

4. Kurang Berpengaruh diberi nilai dua

5. Tidak Berpengaruh diberi nilai satu

Skala likert pada variabel penilaian meliputi :

1. Sangat setuju diberi nilai lima

2. Setuju diberi nilai empat

3. Cukup Setuju diberi nilai tiga

4. Kurang Setuju diberi nilai dua

5. Tidak Setuju diberi nilai satu

\section{Hasil Analisis}

Berdasarkan kesesuaian adalah hasil perbandingan skor kinerja/pelaksana dengan skor harapan. Tingkat kesesuaian inilah yang akan menentukan urutan prioritas peningkatan faktor-faktor yang mempengaruhi kepuasan nasabah.

Adapun rumus yang digunakan adalah

$$
\mathrm{Tki}=\frac{\mathrm{Xi}}{\mathrm{Yi}} \times 100 \%
$$

Dimana :

Tki $=$ Tingkat Kesesuaian responden

$\mathrm{Xi}=$ Skor penilaian kinerja Layanan

Yi $=$ Skor penilaian harapan Nasabah

Dan dari variabel yang disebutan di atas, maka sumbu mendatar (X) akan diisi oleh skor Layanan dalam tingkat kinerja karyawan untuk memberikan kepuasan pada para nasabah, sedangkan sumbu tegak (Y) akan diisi oleh skor tingkat harapan nasabah. Dalam penyederhanaan rumus, maka untuk setiap faktor yang mempengaruhi kepuasan nasabah dengan:

$$
\begin{aligned}
& \mathrm{X}=\frac{\sum \mathrm{Xi}}{\mathrm{n}} \\
& ¥=\frac{\sum \mathrm{Yi}}{\mathrm{n}}
\end{aligned}
$$

Dimana

$\mathrm{X}=$ Skor rata-rata tingkat pelaksana/kepuasan

$\mathrm{Y}=$ Skor rata-rata tingkat harapan

$\mathrm{N}=$ Jumlah responden

Pembahasan Penelitian

1. Teistis (Rabbaniyah)

A. Kepatuhan dan Ketaatan Karyawan pada SOP 
Tabel 2

Tingkat Harapan Nasabah Terhadap Kepatuhan dan Ketaatan Karyawan pada SOP dalam Melaksanakan Tugasnya

\begin{tabular}{|l|c|c|c|}
\hline \multicolumn{1}{|c|}{ Keterangan } & Bobot & Jumlah & Total \\
\hline Sangat tidak setuju & 1 & 0 & 0 \\
\hline Tidak setuju & 2 & 0 & 0 \\
\hline Ragu-ragu & 3 & 0 & 0 \\
\hline Setuju & 4 & 53 & 212 \\
\hline Sangat setuju Total & 5 & 27 & 135 \\
\hline \multicolumn{2}{|c|}{} & $\mathbf{3 4 7}$ \\
\hline
\end{tabular}

Sumber: Data diolah (2016)

Tabel 3

Penilaian Nasabah Terhadap Kepatuhan dan Ketaatan Karyawan pada SOP dalam Melaksanakan Tugasnya

\begin{tabular}{|l|c|c|c|}
\hline \multicolumn{1}{|c|}{ Keterangan } & Bobot & Jumlah & Total \\
\hline Sangat tidak setuju & 1 & 0 & 0 \\
\hline Tidak setuju & 2 & 0 & 0 \\
\hline Ragu-ragu & 3 & 13 & 39 \\
\hline Setuju & 4 & 44 & 176 \\
\hline Sangat setuju Total & 5 & 23 & 115 \\
\hline \multicolumn{2}{|c|}{} & $\mathbf{3 3 0}$ \\
\hline
\end{tabular}

Sumber: Data diolah (2016)

Dari kedua data yang diperoleh tersebut akan menghasilkan tingkat kesesuaian yang sebesar $95,10 \%=\left(\frac{330}{347} \times 100 \%\right)$

B. Kejujuran dalam Memasarkan Produk

Tabel 4

Tingkat Harapan Nasabah Terhadap Kejujuran Karyawan dalam Memasarkan Produknya

\begin{tabular}{|l|c|c|c|}
\hline \multicolumn{1}{|c|}{ Keterangan } & Bobot & Jumlah & Total \\
\hline Sangat tidak setuju & 1 & 0 & 0 \\
\hline Tidak setuju & 2 & 0 & 0 \\
\hline Ragu-ragu & 3 & 0 & 0 \\
\hline Setuju & 4 & 46 & 184 \\
\hline Sangat setuju Total & 5 & 34 & 170 \\
\hline \multicolumn{2}{|c|}{} & $\mathbf{3 5 4}$ \\
\hline
\end{tabular}

Sumber: Data diolah (2016)

Tabel 5

Penilaian Nasabah Terhadap Kejujuran Karyawan dalam Memasarkan Produknya

\begin{tabular}{|l|c|c|c|}
\hline \multicolumn{1}{|c|}{ Keterangan } & Bobot & Jumlah & Total \\
\hline Sangat tidak setuju & 1 & 1 & 1 \\
\hline Tidak setuju & 2 & 0 & 0 \\
\hline Ragu-ragu & 3 & 16 & 48 \\
\hline Setuju & 4 & 44 & 176 \\
\hline Sangat setuju Total & 5 & 19 & 95 \\
\hline \multicolumn{2}{|c|}{} & $\mathbf{3 2 0}$ \\
\hline
\end{tabular}


Sumber: Data diolah (2016)

Dari kedua data yang diperoleh tersebut akan menghasilkan tingkat kesesuaian yang sebesar $90,40 \%=\left(\frac{320}{354} \times 100 \%\right)$

2. Etis (Akhlaqiyyah)

Dalam variabel Etis (Akhlaqiyyah) terdapat dua indikator sebagai tolok ukurnya yaitu akhlak dan etika yang dimiliki karyawan bank.

A. Akhlak yang Baik

Tabel 6

Tingkat Harapan Nasabah Bahwa Karyawan Bank Mempunyai Akhlak yang Baik

\begin{tabular}{|l|c|c|c|}
\hline \multicolumn{1}{|c|}{ Keterangan } & Bobot & Jumlah & Total \\
\hline Sangat tidak setuju & 1 & 0 & 0 \\
\hline Tidak setuju & 2 & 0 & 0 \\
\hline Ragu-ragu & 3 & 0 & 0 \\
\hline Setuju & 4 & 37 & 148 \\
\hline Sangat setuju Total & 5 & 43 & 215 \\
\hline \multicolumn{2}{|c|}{} & $\mathbf{3 6 3}$ \\
\hline
\end{tabular}

Sumber: Data diolah (2016)

Tabel 7

Penilaian Nasabah Bahwa Karyawan Bank Mempunyai Akhlak yang Baik

\begin{tabular}{|l|c|c|c|}
\hline \multicolumn{1}{|c|}{ Keterangan } & Bobot & Jumlah & Total \\
\hline Sangat tidak setuju & 1 & 0 & 0 \\
\hline Tidak setuju & 2 & 2 & 4 \\
\hline Ragu-ragu & 3 & 10 & 30 \\
\hline Setuju & 4 & 38 & 152 \\
\hline Sangat setuju Total & 5 & 30 & 150 \\
\hline \multicolumn{2}{|c|}{} & $\mathbf{3 3 6}$ \\
\hline
\end{tabular}

Sumber: Data diolah (2016)

Dari kedua data yang diperoleh tersebut akan menghasilkan tingkat kesesuaian yang sebesar $92,56 \%=\left(\frac{336}{363} \times 100 \%\right)$

B. Etika yang Baik

Tabel 8

Tingkat Harapan Nasabah Bahwa Karyawan Bank Mempunyai Etika yang Baik

\begin{tabular}{|l|c|c|c|}
\hline \multicolumn{1}{|c|}{ Keterangan } & Bobot & Jumlah & Total \\
\hline Sangat tidak setuju & 1 & 0 & 0 \\
\hline Tidak setuju & 2 & 0 & 0 \\
\hline Ragu-ragu & 3 & 0 & 0 \\
\hline Setuju & 4 & 39 & 156 \\
\hline Sangat setuju Total & 5 & 41 & 205 \\
\hline \multicolumn{2}{|c|}{} & $\mathbf{3 6 1}$ \\
\hline
\end{tabular}

Sumber: Data diolah (2016) 
Tabel 9

Penilaian Nasabah Bahwa Karyawan Bank Mempunyai Etika yang Baik

\begin{tabular}{|l|c|c|c|}
\hline \multicolumn{1}{|c|}{ Keterangan } & Bobot & Jumlah & Total \\
\hline Sangat tidak setuju & 1 & 0 & 0 \\
\hline Tidak setuju & 2 & 0 & 0 \\
\hline Ragu-ragu & 3 & 9 & 27 \\
\hline Setuju & 4 & 36 & 144 \\
\hline Sangat setuju Total & 5 & 35 & 175 \\
\hline \multicolumn{2}{|c|}{} & $\mathbf{3 4 6}$ \\
\hline
\end{tabular}

Sumber: Data diolah (2016)

Dari kedua data yang diperoleh tersebut akan menghasilkan tingkat kesesuaian yang sebesar $95,84 \%=\left(\frac{346}{361} \times 100 \%\right)$

3. Realistis (Al Waqi'iyyah)

A. Berpenampilan yang Baik

Tabel 10

Tingkat Harapan Nasabah Bahwa Karyawan Bank Berpenampilan Bersih, Rapi, Bersahaja dan Berbusana Muslim

\begin{tabular}{|l|c|c|c|}
\hline \multicolumn{1}{|c|}{ Keterangan } & Bobot & Jumlah & Total \\
\hline Sangat tidak setuju & 1 & 0 & 0 \\
\hline Tidak setuju & 2 & 0 & 0 \\
\hline Ragu-ragu & 3 & 0 & 0 \\
\hline Setuju & 4 & 44 & 176 \\
\hline Sangat setuju Total & 5 & 36 & 180 \\
\hline \multicolumn{2}{|c|}{} & $\mathbf{3 5 6}$ \\
\hline
\end{tabular}

Sumber: Data diolah (2016)

Tabel 11

Penilaian Nasabah Bahwa Karyawan Bank Berpenampilan Bersih, Rapi, Bersahaja dan Berbusana Muslim

\begin{tabular}{|l|c|c|c|}
\hline \multicolumn{1}{|c|}{ Keterangan } & Bobot & Jumlah & Total \\
\hline Sangat tidak setuju & 1 & 0 & 0 \\
\hline Tidak setuju & 2 & 0 & 0 \\
\hline Ragu-ragu & 3 & 9 & 27 \\
\hline Setuju & 4 & 27 & 108 \\
\hline Sangat setuju Total & 5 & 44 & 220 \\
\hline \multicolumn{2}{|c|}{} & $\mathbf{3 5 5}$ \\
\hline
\end{tabular}

Sumber: Data diolah (2016)

Dari kedua data yang diperoleh tersebut akan menghasilkan tingkat kesesuaian yang sebesar $99,72 \%=\left(\frac{355}{356} \times 100 \%\right)$

B. Bekerja secara Profesional

Tabel 12

Tingkat Harapan Nasabah Bahwa Karyawan Bank Selalu Bekerja Professional Dan Berpengalaman

\begin{tabular}{|c|c|c|c|}
\hline Keterangan & Bobot & Jumlah & Total \\
\hline Sangat tidak setuju & 1 & 0 & 0 \\
\hline
\end{tabular}




\begin{tabular}{|l|c|c|c|}
\hline Tidak setuju & 2 & 0 & 0 \\
\hline Ragu-ragu & 3 & 0 & 0 \\
\hline Setuju & 4 & 33 & 132 \\
\hline Sangat setuju Total & 5 & 47 & 235 \\
\hline \multicolumn{2}{|c|}{ Tot } \\
\hline
\end{tabular}

Sumber: Data diolah (2016)

Tabel 13

Penilaian Nasabah Bahwa Karyawan Bank Selalu Bekerja Professional Dan Berpengalaman

\begin{tabular}{|l|c|c|c|}
\hline \multicolumn{1}{|c|}{ Keterangan } & Bobot & Jumlah & Total \\
\hline Sangat tidak setuju & 1 & 0 & 0 \\
\hline Tidak setuju & 2 & 0 & 0 \\
\hline Ragu-ragu & 3 & 11 & 33 \\
\hline Setuju & 4 & 45 & 180 \\
\hline Sangat setuju Total & 5 & 24 & 120 \\
\hline \multicolumn{2}{|c|}{} & $\mathbf{3 3 3}$ \\
\hline
\end{tabular}

Sumber: Data diolah (2016)

Dari kedua data yang diperoleh tersebut akan menghasilkan tingkat kesesuaian yang sebesar $90,74 \%=\left(\frac{333}{367} \times 100 \%\right)$

4. Humanistis (Insaniyyah)

A. Memiliki Empati yang Tinggi

Tabel 14

Tingkat Harapan Nasabah Bahwa Karyawan Bank Mempunyai Empati Yang Tinggi Terhadap Semua Nasabah

\begin{tabular}{|l|c|c|c|}
\hline \multicolumn{1}{|c|}{ Keterangan } & Bobot & Jumlah & Total \\
\hline Sangat tidak setuju & 1 & 0 & 0 \\
\hline Tidak setuju & 2 & 0 & 0 \\
\hline Ragu-ragu & 3 & 0 & 0 \\
\hline Setuju & 4 & 46 & 184 \\
\hline Sangat setuju Total & 5 & 34 & 170 \\
\hline \multicolumn{2}{|c|}{} & $\mathbf{3 5 4}$ \\
\hline
\end{tabular}

Sumber: Data diolah (2016)

Tabel 15

Penilaian Nasabah Bahwa Karyawan Bank Mempunyai Empati Yang Tinggi Terhadap Semua Nasabah

\begin{tabular}{|l|c|c|c|}
\hline \multicolumn{1}{|c|}{ Keterangan } & Bobot & Jumlah & Total \\
\hline Sangat tidak setuju & 1 & 0 & 0 \\
\hline Tidak setuju & 2 & 0 & 0 \\
\hline Ragu-ragu & 3 & 11 & 33 \\
\hline Setuju & 4 & 46 & 184 \\
\hline Sangat setuju Total & 5 & 23 & 115 \\
\hline \multicolumn{2}{|c|}{} & $\mathbf{3 3 2}$ \\
\hline
\end{tabular}

Sumber: Data diolah (2016) 
Dari kedua data yang diperoleh tersebut akan menghasilkan tingkat kesesuaian yang sebesar $93,79 \%=\left(\frac{332}{354} \times 100 \%\right)$

B. Suka Membantu yang Membutuhkan

Tabel 16

Tingkat Harapan Nasabah Bahwa Karyawan Bank Selalu Bersedia Membantu Kesulitan Yang Dihadapi Nasabah Dalam Segala Hal

\begin{tabular}{|l|c|c|c|}
\hline \multicolumn{1}{|c|}{ Keterangan } & Bobot & Jumlah & Total \\
\hline Sangat tidak setuju & 1 & 0 & 0 \\
\hline Tidak setuju & 2 & 0 & 0 \\
\hline Ragu-ragu & 3 & 0 & 0 \\
\hline Setuju & 4 & 43 & 172 \\
\hline Sangat setuju Total & 5 & 37 & 185 \\
\hline \multicolumn{2}{|c|}{} & $\mathbf{3 5 7}$ \\
\hline
\end{tabular}

Sumber: Data diolah (2016)

Tabel 17

Penilaian Nasabah Bahwa Karyawan Bank Selalu Bersedia Membantu Kesulitan Yang Dihadapi Nasabah Dalam Segala Hal

\begin{tabular}{|l|c|c|c|}
\hline \multicolumn{1}{|c|}{ Keterangan } & Bobot & Jumlah & Total \\
\hline Sangat tidak setuju & 1 & 0 & 0 \\
\hline Tidak setuju & 2 & 0 & 0 \\
\hline Ragu-ragu & 3 & 20 & 60 \\
\hline Setuju & 4 & 33 & 132 \\
\hline Sangat setuju Total & 5 & 27 & 135 \\
\hline \multicolumn{2}{|c|}{ T27 } \\
\hline
\end{tabular}

Sumber: Data diolah (2016)

Dari kedua data yang diperoleh tersebut akan menghasilkan tingkat kesesuaian yang sebesar $91,60 \%=\left(\frac{327}{357} \times 100 \%\right)$

Tabel 18

Rata-Rata Kesesuaian Penilaian Kinerja Dan Penilaian Harapan Nasabah Pada Faktor-Faktor yang Mempengaruhi Kepuasan Nasabah Terhadap Implementasi Syariah Marketing Pada PT. Bank Syariah Mandiri Cabang Malang

\begin{tabular}{|c|l|c|c|c|c|}
\hline No. & \multicolumn{1}{|c|}{ Faktor-Faktor } & $\begin{array}{c}\text { Penilaian } \\
\text { Kinerja }\end{array}$ & $\begin{array}{c}\text { Penilaian } \\
\text { Harapan }\end{array}$ & $\overline{\mathbf{X}}$ & $\overline{\mathbf{Y}}$ \\
\hline 1 & $\begin{array}{l}\text { Karyawan bank selalu patuh dan } \\
\text { taat pada SOP saat melaksanakan } \\
\text { tugasnya }\end{array}$ & 330 & 347 & 4,13 & 4,34 \\
\hline 2 & $\begin{array}{l}\text { Karyawan bank selalu jujur dalam } \\
\text { memasarkan produknya }\end{array}$ & 320 & 354 & 4,00 & 4,43 \\
\hline 3 & $\begin{array}{l}\text { Karyawan bank mempunyai } \\
\text { akhlak yang baik (sopan dan } \\
\text { santun) }\end{array}$ & 336 & 363 & 4,20 & 4,54 \\
\hline 4 & $\begin{array}{l}\text { Karyawan bank mempunyai etika } \\
\text { yang baik }\end{array}$ & 346 & 361 & 4,33 & 4,51 \\
\hline 5 & $\begin{array}{l}\text { Karyawan bank berpenampilan } \\
\text { bersih, rapi, bersahaja dan }\end{array}$ & 355 & 356 & 4,44 & 4,45 \\
\hline
\end{tabular}




\begin{tabular}{|c|l|l|l|l|l|}
\hline & berbusana muslim & & & & \\
\hline 6 & $\begin{array}{l}\text { Karyawan bank selalu bekerja } \\
\text { professional dan berpengalaman } \\
\text { (menguasai dengan betul tentang } \\
\text { produk yang ditawarkan) }\end{array}$ & 333 & 367 & 4,16 & 4,59 \\
\hline 7 & $\begin{array}{l}\text { Karyawan bank mempunyai } \\
\text { empati yang tinggi terhadap } \\
\text { semua nasabah }\end{array}$ & 332 & 354 & 4,15 & 4,58 \\
\hline 8 & $\begin{array}{l}\text { Karyawan bank selalu bersedia } \\
\text { membantu kesulitan yang dihadapi } \\
\text { nasabah dalam segala hal }\end{array}$ & 327 & 357 & 4,09 & 4,46 \\
\hline Rata-rata (X) dan (Y) & & $\mathbf{4 , 1 9}$ & $\mathbf{4 , 4 7}$ \\
\hline
\end{tabular}

Sumber: Data diolah (2016)

Analisis Stategi untuk Meningkatkan Kepuasan Nasabah dalam Implementasi Syariah Marketing Pada PT. Bank Syariah Mandiri Cabang Malang

\section{Gambar 1}

Diagram Kartesius dari Faktor-Faktor yang Mempengaruhi Kepuasan Nasabah terhadap Implementasi Syariah Marketing pada PT. Bank Syariah Mandiri Cabang Malang

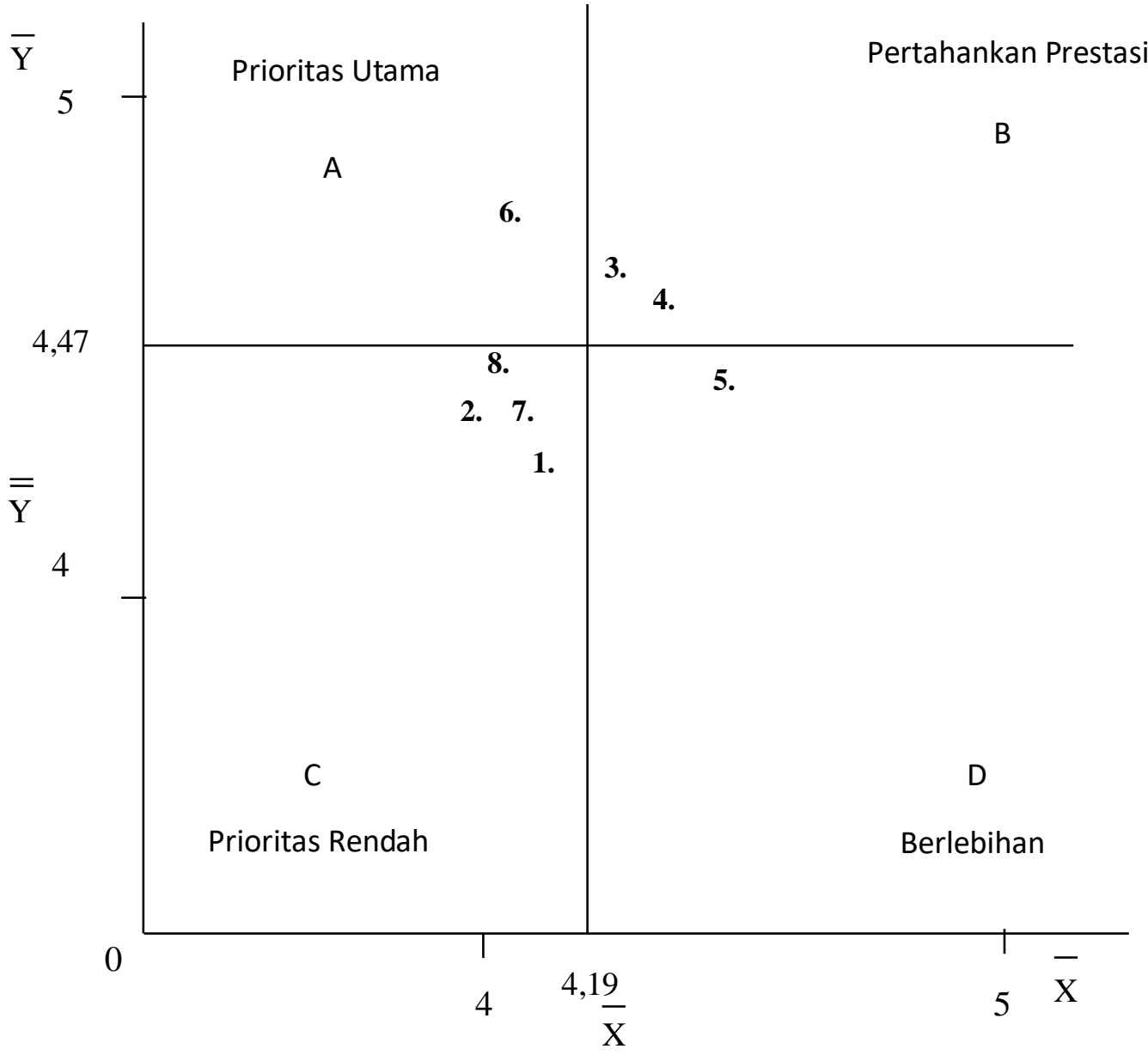


Keterangan :

A. Menunjukkan faktor atau atribut yang dianggap mempengaruhi kepuasan nasabah, termasuk unsur-unsur syariah marketing yang dianggap sangat penting, namun dalam implementasinya belum sesuai dengan keinginan nasabah. Sehingga masih belum memuaskan dan perlu diprioritaskan oleh pihak bank.

Faktor-faktor yang termasuk dalam kuadran ini adalah:

1. Karyawan bank selalu bekerja professional dan berpengalaman (menguasai dengan betul tentang produk yang ditawarkan). (6)

B. Menunjukkan unsur pokok syariah marketing yang telah berhasil dilaksanakan pihak bank, untuk itu wajib dipertahankan. Dianggap sangat penting dan sangat memuaskan.

Faktor-faktor yang termasuk dalam kuadran ini adalah:

1. Karyawan bank mempunyai akhlak yang baik (sopan dan santun). (3)

2. Karyawan bank mempunyai etika yang baik. (4)

C. Menunjukkan bahwa faktor-faktor yang mempengaruhi kepuasan nasabah dalam kuadran ini masih dianggap kurang penting bagi nasabah. Sedangkan kualitas pelaksanaannya biasa atau cukup saja.

Adapun faktor yang termasuk dalam kuadran ini adalah:

1. Karyawan bank selalu patuh dan taat pada SOP saat melaksanakan tugasnya. (1)

2. Karyawan bank selalu jujur dalam memasarkan produknya. (2)

3. Karyawan bank mempunyai empati yang tinggi terhadap semua nasabah. (7)

4. Karyawan bank selalu bersedia membantu kesulitan yang dihadapi nasabah dalam segala hal. (8)

D. Menunjukkan bahwa faktor yang mempengaruhi kepuasan nasabah yang berada dalam kuadran ini dinilai berlebihan dalam pelaksanaannya. Hal ini terutama disebabkan karena nasabah menganggap tidak terlalu penting terhadap faktor tersebut, akan tetapi pelaksanaannya dilakukan dengan baik sekali oleh pihak bank sehingga sangat memuaskan akan tetapi jadi lebih mahal.

Faktor-faktor yang mempengaruhi kepuasan nasabah dalam implementasi syariah marketing adalah:

1. Karyawan bank berpenampilan bersih, rapi, bersahaja dan berbusana muslim. (5)

\section{KESIMPULAN}

1. Tingkat kepuasan nasabah terhadap karakteristik Syariah Marketing dimulai dari variabel Teistis (Rabbaniyah) yang terdiri dari dua item, memiliki tingkat kepuasan sebesar 95,1 dan 90,40. Etis (Akhlaqiyyah) sebesar 92,56\% dan 95,84\%

Realistis (Al Waqi'iyyah) sebesar 99,72\% dan 90,74\% , Humanistis (Insaniyyah) sebesar 93,79\% dan 91,60\%. Sehingga dapat disimpulkan nasabah sudah merasa sangat puas dengan pelayanan dari karyawan PT. Bank Syariah Mandiri Cabang Malang. Untuk data rata-rata kesesuaian penilaian kinerja dan penilaian harapan nasabah pada faktor-faktor yang mempengaruhi kepuasan nasabah terhadap implementasi syariah marketing pada PT. Bank Syariah Mandiri Cabang Malang, penilaian kinerja 4,19 dan harapan nasabah 4,47, hal ini dapat disimpulkan bahwa kinerja karyawan PT. Bank Syariah Mandiri Cabang Malang harus ditingkatkan.

2. Sesuai dengan hasil analisis stategi untuk meningkatkan kepuasan nasabah dalam implementasi Syariah Marketing pada PT. Bank Syariah Mandiri Cabang Malang yaitu prioritas utama pada kwadran A meningkatkan karyawan bank selalu bekerja professional dan berpengalaman (menguasai dengan betul tentang produk yang ditawarkan). Pada kwadran B, strategi berikutnya adalah mempertahankan prestasi dengan selalu meningkatkan akhlak dan etika yang baik. Pada kwadran C, strategi prioritas rendah, PT. Bank Syariah Mandiri Cabang Malang, harus tetap 
diperhatikan, yaitu pada variabel kepatuhan dan ketaatan karyawan serta kejujuran karyawan. Termasuk juga empati dan kesediaan karyawan merupakan strategi prioritas rendah namun harus selalu diperhatikan untuk meningkatkan kepuasan karyawan. Sedangkan pada kwadran D, strategi yang berlebihan, dalam arti hal ini sudah sangat baik dilakukan tetapi menurut karyawan tidak dianggap penting adalah karyawan bank berpenampilan bersih, rapi, bersahaja dan berbusana muslim.

\section{DAFTAR PUSTAKA}

Amstrong, Gary \& Philip, Kotler. 1996. Dasar-dasar Pemasaran. Jilid 1, Alih Bahasa Alexander Sindoro dan Benyamin Molan, Prenhalindo, Jakarta.

Nazmudin. 2012. Pengaruh Marketing Syariah dan Etika Pelayanan Terhadap Kepuasan Pemegang Polis (Studi Pada AJB Bumi Putra 1912 Cabang Syariah Semarang). IAIN Walisongo. Semarang.

Kartajaya, Hermawan, \& Sula, Syakir, Muhammad. 2006. Syariah Marketing. Bandung: PT. Mizan Pustaka

Kotler, Philip. 1997. Manajemen Pemasaran :Analisis, Perencanaan, Implementasi dan Kontrol, Ed. 9, Jilid 1, PT Prenhallindo, Jakarta.

Supranto, J. 1991. Metode Riset, FE Universitas Indonesia, Jakarta.

Sugiyono. 2004. Metode Penelitian Binis, Alfabeta, Bandung.

Suharsimi Arikunto. 2002. Prosedur Penelitian, Rineka Cipta, Jakarta.

Susilowati, Nurdian, dkk. 2008. Pengaruh Kepemimpinan Dosen, Kualitas Layanan Akademik dan Administrasi Terhadap Kepuasan Mahasiswa Fakultas Ekonomi Unnes.

Swasta DH, Basu.1996. Azas-azaz Marketing, Liberty, Yogyakarta.

Simamora, Henry. 2000. Manajemen Pemasaran Internasional, Jilid 1. Vol 4. Penerbit Salemba, Jakarta.

Jakarta. 2002. Manajemen Pemasaran Internasional, Jilid 2 Salemba Empat,

Tjiptono, Fjiptono. 2002. Strategi Pemasaran, Edisi.2, Cet.2, Andi Offset, Yogyakarta. 2004. Manajemen Jasa, Andi, Yogyakarta.

Yuliana Sari, Erlina. 2013. Implementasi Pemasaran Islami (Marketing Syariah) Serta Pengaruhnya Terhadap Minat Anggota Pada KJKS Binama Semarang. IAIN Walisongo. Semarang

Zeithaml V \& Bitner M. 1996. Services Marketing, McGraw Hill International Editions. 